Alden Electronics

Vaisala Inc.

Belfort Instrument Company

Office of Naval Research

University of Oklahoma Press

Atmospheric Instrumentation Research, Inc.

System Technology Associated, Inc.

Vaisala Finland

Solar Light Co., Inc.

Handar

Atmospheric Instrumentation Research, Inc.

UCAR

Weather Information Technology

Rotronics Instrumentation

Setra Systems

Meteoquest, Inc.

Mesa Systems Co.

Yankee Environmental Systems, Inc.

AMS Publications, Preprints, etc.

652

682

761

762

770

807

809

828

829

843

847
Collected Works of Henry Stommel: Volumes 1-3

The Representation of Cumulus Convection in Numerical

Models, MM. No. 46

Back to the Future: Old and New Forecasting Techniques (Workshop)

Weatherwise

Tenth Conf. on Atmospheric and Oceanic Waves and Stability

AMS Newsletter Online

Fourth Symposium on Education

JPO Cumulative Index

AMS Silk Ties and Scarves

AMS Polo Shirts

Employment Announcements

(-) Copyright 1996, American Meteorological Society (AMS). Permission to use figures, tables, and brief excerpts from this journal in scientific and educational work is hereby granted, provided source is acknowledged. Any use of the material in this journal that is considered to be "fair use" under Section 107 or that satisfies the conditions specified in Section 108 of the U.S. Copyright Law (17 USC, as revised by P.L. 94-553) does not require the Society's permission. Items that do not bear their own separate copyright notices either are in the public domain or are U.S. Government works for which copyright protection is not available. Authorization to photocopy items bearing individual AMS copyright notices at the bottom of their first page is granted by the AMS for libraries and other users registered with the Copyright Clearance Center (CCC) Transactional Reporting Service, provided the copies are for internal or personal use, or for the internal or personal use of specific clients, and further provided the base of $\$ 4.25$ per copy $+\$ 0.29$ per page is paid directly to the CCC, 222 Rosewood Drive, Danvers, MA 01923, and that the following fee code for this journal is reported with the payment to CCC: 0003-0007/91 $\$ 4.25+\$ 0.29$. Republication, systematic reproduction, and any other use of any material in this journal, unless exempted by the above statements, requires written permission or license from the AMS. Additional details are provided in the AMS Copyright Policies, available from the AMS at $617-227-2425$ or amspubs@ ametsoc.org. "American Meteorological Society," the Seal of the American Meteorological Society, and the AMS Seal of Approval are registered trademarks of the American Meteorological Society.

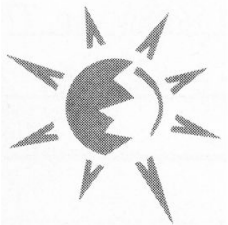

\title{
EMPLOYMENT ANHOUNCEMENTS
}

\section{The American Meteorological Society publishes a monthly newsletter announcing employment opportunities for positions in the atmospheric and oceanic fields.}

Members and nonmembers may subscribe to the announcements at an annual (12 monthly issues) subscription rate of $\$ 15$ for AMS members and $\$ 30$ for nonmembers. (Both members and nonmembers, kindly add $\$ 10$ for airmailing to a foreign address.) After July 1, half-year subscriptions (for July through December issues) are available at one half of the above annual prices

Organizations with openings to be filled by qualified individuals seeking positions in the atmospheric and related fields should contact the American Meteorological Society, 45 Beacon Street, Boston, MA 02108-3693, 617-2272426, ext. 209, for announcement guidelines and charges. ASCII diskettes are invited. You may also submit announcements via the Internet: amsempl@ametsoc.org. 